\title{
Androgen Responses during Physical Exercise
}

\author{
J. R. SUTTON, M. J. COLEMAN, J. CASEY, L. LAZARUS
}

British Medical fournal, 1973, 1, 520-522

\section{Summary}

The serum androgen response to physical exercise was studied in highly trained athletes and in normal male medical students. Serum androgens rose in response to maximal exercise and the rise was independent of serum luteinizing hormone. No response was obtained with submaximal exercise.

\section{Introduction}

Physical exercise is a stimulus to the secretion of many hormones, including growth hormone (Roth et al., 1962; Sutton et al., 1968), cortisol (Sutton et al., 1972), and catecholamines (Vendsalu, 1960). These hormonal changes presumably are associated with the metabolic changes occurring during exercise. As testosterone, the major male androgen, exerts a potent protein anabolic action and is responsible for the maintenance of muscle and bone tissue, studies of the serum androgen response to physical exercise were performed.

\section{Subjects and Methods}

Fourteen male rowers, mean age 24.4 years (range 18.9 to 28.3 years), were studied before and after morning and afternoon training sessions on the same day. The rowers were of Olympic standard and approaching peak physical fitness. The morning training session of 60 minutes duration began at 7 a.m. and consisted of maximal exercise in the form of running and calisthenics. The afternoon session of 60 minutes duration began at 4.30 p.m. and consisted of submaximal rowing training.

Seven male swimmers, mean age 17.0 years (range 15.2 to $19 \cdot 1$ years), and four female swimmers, mean age 14.7 years

Garvan Institute of Medical Research and Department of Surgery, St. Vincent's Hospital, Sydney, Australia

J. R. SUTTON, M.B., M.R.A.C.P., Research Fellow

M. J. COLEMAN, M.B., B.S., Research Fellow

J. CASEY, M.B., M.R.A.C.P., Staff Endocrinologist

L. LAZARUS, M.B., F.R.A.C.P., Director (range 13.7 to 15.4 years), were studied at 5.30 a.m. before a morning training session and at 7.30 a.m. after a subsequent training session which concluded in a maximal-effort 800 -metre swim. Both the male and female swimmers were of Olympic standard. Estimations were made on venous blood collected from an antecubital vein.

Sequential studies on four informed normal male medical students mean age 22.6 years (range 21.0 to 23.4 years) were carried out before, during, and after 20 minutes' exercise on a bicycle ergometer at 900 kilopond metres per minute. The students presented to the laboratory between 8 and 9 a.m. after an overnight fast. Venous blood samples were collected from an antecubital vein via an indwelling polyethylene catheter kept patent by a slow intravenous infusion of normal saline. Each subject rested for at least 30 minutes in the supine position before starting exercise. No subject tested had been treated with androgen preparations.

Measurements of total serum androgens, serum growth hormone, serum luteinizing hormone, serum cortisol, and plasma glucose were performed during the studies. Total serum androgens were the 17- $\beta$ hydroxy steroids measured by a modification of the protein binding technique of Horton et al. (1967). Testosterone was measured by a similar competitive protein binding technique after chromotography of the serum extract on Sephadex LH 20. Percentage testosterone bound to protein was measured in diluted serum by the method of Forrest et al. (1968). Serum cortisol was measured by a modification of the protein binding technique of Murphy (1967). Serum growth hormone and serum luteinizing hormone were measured by radioimmunoassay using modifications of the method of Hales and Randle (1963). Serum growth hormone levels are reported in microunits of the World Health Organization reference standard and serum luteinizing hormone levels in nanogrammes of the National Institute of Health Standard LER-907. Plasma glucose was measured on an autoanalyser by a modification of the ferricyanide method of Hoffman (1937).

\section{Results}

The mean values and significant differences between hormone and glucose measurements before and after exercise are given for the rowers and swimmers in the table. There were significant

Mean ( \pm S.E. of Mean) Hormonal and Glucose Response to Exercise in 14 Male Rowers, Seven Male Swimmers, and Four Female Swimmers. P Values indicate Degree of Significance between Measurements Before and After Exercise

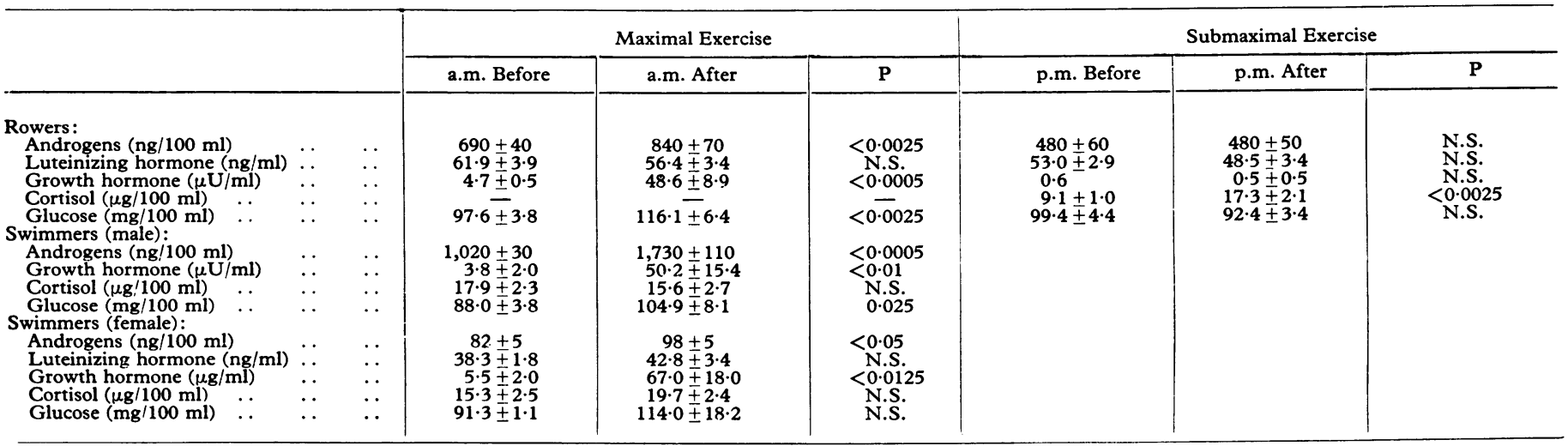

N.S. $=$ Not significant. 
rises in serum androgens and growth hormone in both rowers and swimmers after maximal exercise but insignificant changes in these measurements after submaximal exercise. There was no associated rise in levels of serum luteinizing hormone in the rowers and female swimmers. Estimations of luteinizing hormone before and after exercise were not performed for the male swimmers. Serum cortisol levels were significantly raised in the rowers during the afternoon training session and also in the studies on the students. There was no significant alteration in serum cortisol in the swimmers.

The sequential mean hormonal responses of the four male medical students are shown in the chart. Serum androgens were raised after 10 minutes' exercise and reached a peak at 20 minutes. There were no corresponding changes in serum luteinizing hormone, but significant alterations in serum cortisol and growth hormone were observed. Specific testosterone assays performed on serum from the male students during exercise showed that the rise in androgens was predominently due to a rise in testosterone. There was no alteration in protein binding of testosterone during exercise. Plasma glucose estimations performed during all studies showed significant rises during exercise.
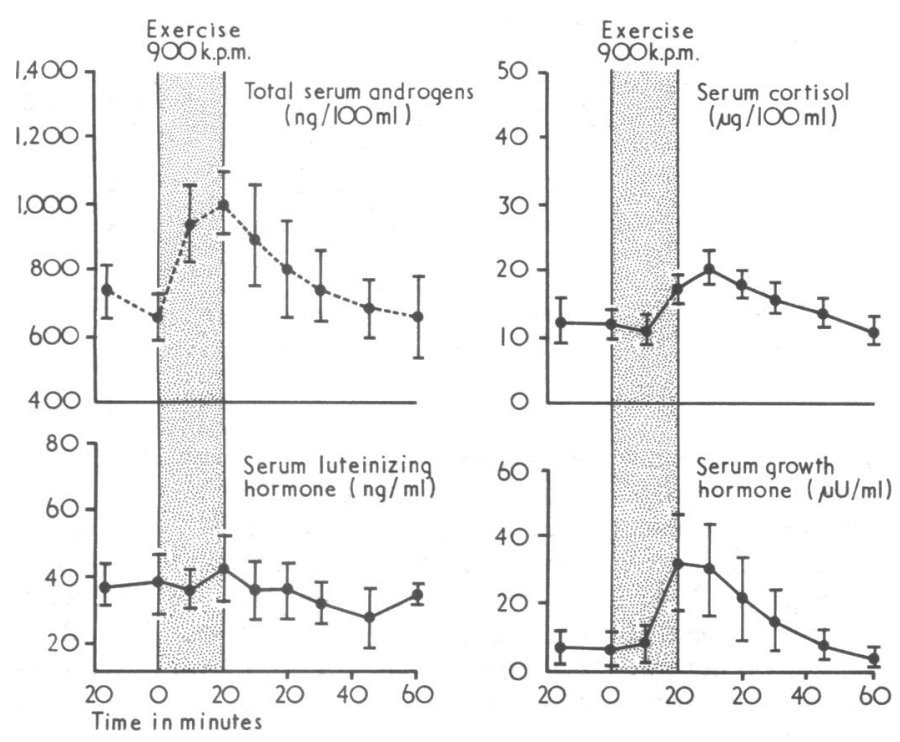

Mean ( $t$ S.E. of Mean) hormonal responses in four normal male medical students during 20 minutes' exercise at 900 kilopond metres/min.

\section{Discussion}

A rise in serum androgens was observed in all subjects performing maximal exercise. There was no alteration in serum androgens during submaximal exercise, which suggests that the rise, as previously shown with growth hormone (Sutton et al., 1969), is related to the intensity of the exercise. High androgen levels were observed in the male swimmers with the mean preexercise level being above the upper limit of normal一that is, $1,000 \mathrm{ng} / 100 \mathrm{ml}$-for this laboratory. This is of interest in view of a recent report (Andrew et al., 1972) showing increased height and weight of competitive swimmers compared with their nonathletic counterparts. The raised level of androgen during exercise may act in association with growth hormone to increase the pubertal growth velocity.

The androgen rise was independent of serum luteinizing hormone. Luteinizing hormone is generally accepted as the pituitary gonadotrophin controlling testosterone secretion. It has not, however, been found in this laboratory to be raised in association with the testosterone rise observed in the physiological situations, sleep and exercise. During some of the present sequential studies large, spontaneous fluctuations in serum luteinizing hormone levels were observed similar to those reported by Yen et al. (1972), but these were not followed by significant changes in serum androgens. These findings support the lack of association between androgens and luteinizing hormone observed by other workers (Faiman and Winter, 1971; Cartersen et al., 1972) and indicate a need for reexamining the control of testosterone secretion.

During exercise androgens may rise because of either increased secretion or decreased clearance or both. Stimuli such as catecholamines (Eik-Nes, 1969a), protaglandins (Eik-Nes, 1969b), and alterations in testicular blood flow may be responsible for increased secretion. Catecholamines, particularly noradrenalin, are known to rise during exercise (Vendsalu, 1960) and they have been shown to stimulate the synthesis and secretion of testosterone by the testis (Eik-Nes, 1964). The contribution of adrenal androgens and other peripherally synthesized steroid precursors of testosterone to the total serum androgens is small (Horton and Tait, 1966) and cannot account for the observed rise during exercise.

Reduced hepatic clearance of androgens may contribute to the rise in androgen levels, since a noticeable decrease in hepatic blood flow during exercise has been found. Wahren et al. (1971), using a work load similar to that used in the present bicycle ergometer studies, found that hepatic blood flow decreased by almost $50 \%$. Thus both decreased hepatic clearance and increased testicular secretion probably contribute to the observed increase in serum androgens.

The role of androgens in exercise is unknown. They may influence the growth and muscular development associated with exercise, possibly in conjunction with growth hormone. Androgens have a well recognized function in maintenance of bone and muscle tissue, and in exercise they may be important in muscle fibre repair and hypertrophy through an enhancing action on protein synthesis (Bartlett; 1953).

In maximal exercise glucose is the major energy substrate. Turnover studies with ${ }^{14} \mathrm{C}$-labelled glucose have shown that while plasma glucose turnover is increased during exercise (Keul et al., 1967) its contribution to energy expenditure may be only $10-15 \%$ of the total (Paul and Issekutz, 1967). It thus appears that muscle glycogen is of particular importance as muscle energy substrate, and exercise increases the ability of muscle tissue to synthesize and store glycogen (Bergstrom and Hultman, 1966). Recent animal studies (Gillespie and Edgerton, 1970) showed that this ability is dependent on adequate testosterone levels and thus the observed rise in testosterone in exercise may be important in utilization and replenishment of muscle glycogen. Testosterone may in addition influence carbohydrate metabolism in muscle by increasing the availability of creatine phosphate (Paulsen, 1968).

The raised androgen levels may further be associated with the aggressiveness and drive necessary to perform maximal exercise and may also contribute to the feeling of well being experienced by athletes who are approaching peak fitness.

We wish to thank Dr. R. Richards, Mr. A. Calaway, Mr. P. Russo, Dr. E. McCloughan, Mr. F. Carlile, Mr. T. Green, and Miss P. Cubis for their co-operation during the studies of the athletes. We also wish to acknowledge the expert technical help of Mrs. V. Yates, Miss R. Page, Mrs. J. McDonald, and Mr. J. Maksvytis, and the secretarial help of Mrs. E. Hartigan and Miss H. Kirkpatrick.

This work was supported by the Life Insurance Medical Research Fund of Australia and New Zealand.

Requests for reprints should be addressed to: Dr. M. J. Coleman, Garvan Institute, St. Vincent's Hospital, Darlinghurst, 2010, Sydney, Australia.

\section{References}

Andrew, G. M., Becklake, M. R., Guleria, J. S., and Bates, D. V. (1972). Fournal of Applied Physiology, 32, 245.

Bergstrom, J., and Hultman, E. (1966). Nature, 210, 309. 
Cartensen, H., Terner, N., Thoren, L., and Wide, L. (1972). Acta Chirurgica Scandinavica, 138, 1 .

Eik-Nes, K. B. (1964). Canadian fournal of Physiology and Pharmacology, $42,671$.

Eik-Nes, K. B. (1969a). American fournal of Physiology, 217, 1764.

Eik-Nes, K. B. (1969b). General and Comparative Endocrinology, Suppl. No. 2, p. 87.

Faiman, C., and Winter, J. S. D. (1971). fournal of Clinical Endocrinology and Metabolism, 33, 186.

Forrest, M. G., Rivarola, M. A., and Migeon, C. J. (1968). Steroids, 12, 323. Gillespie, C. A., and Edgerton, V. R. (1970). Hormone and Metabolic Research, 2, 364.

Hales, C. M., and Randle, P. J. (1963). Biochemical fournal, 88, 137.

Hoffman, W. S. (1937). Fournal of Biological Chemistry, 120, 51

Horton, R., Kato, T., and Sherins, R. (1967). Steroids, 10, 245.

Horton, R., and Tait, J. F. (1966). Fournal of Clinical Investigation, 45,

Keul, J., Doll, E., and Keppler, D. (1967). Experentia, 23, 974.
Murphy, B. E. P. (1967). Fournal of Endocrinology and Metabolism, 27, 973. Paul, P., and Issekutz, B. (1967). Fournal of Applied Physiology, 22, 615.

Paulsen, C. A. (1968). In Textbook of Endocrinology, ed. R. H. Williams,

4th edn., ch. 6, p. 414. Philadelphia, Saunders. $12,577$.

Sutton, J. R., Coleman, M. J., Millar, A. P., Lazarus, L., and Russo, P. (1972). Medical fournal of Australia, 2, 127.

Sutton, J. R., Young, J. D., Lazarus, L., Hickie, J. B., and Maksvytis, J. (1968). Lancet, 2, 1304.

Sutton, J. R., Young, J. D., Lazarus, L., Hickie, J. B., and Maksvytis, J. (1969). Australasian Annals of Medicine, 18, 84.

Vendsalu, A. (1960). Acta Physiologica Scandinavica, 49, Suppl. No. 173,

Wahren, J., Felig, P., Ahlborg, G., and Jorfeldt, L. (1971). Fournal of Clinical Investigation, 50, 2715.

Yen, S. S. C., Tsai, C. C., Najtolin, F., Kandenberg, G., and Ajabor, L. (1972). Journal of Clinical Endocrinology and Metabolism, 34, 671.

\title{
Interaction between Clonidine and Desipramine in Man
}

\author{
ROBIN H. BRIANT, JOHN L. REID, COLIN T. DOLLERY
}

British Medical fournal, 1973, 1, 522-523

\section{Summary}

Interaction between the tricyclic antidepressant desipramine and the antihypertensive agent clonidine has been investigated in five hypertensive patients in a doubleblind placebo controlled study. Introduction of the tricyclic antidepressant led to loss of blood pressure control in four of the patients. The average blood pressure rise in the desipramine period compared with the placebo period was $22 / 15 \mathrm{~mm} \mathrm{Hg}$ in the lying position and $12 / 11$ $\mathrm{mm} \mathrm{Hg}$ standing. Thus addition of a tricyclic antidepressant may lead to loss of blood pressure control in a hypertensive patient treated with clonidine.

\section{Introduction}

The hypotensive action of both bethanidine and guanethidine is impaired by tricyclic antidepressant drugs (Leishman et al., 1963; Mitchell et al., 1967; Mitchell et al., 1970). Their antihypertensive effect is mediated by adrenergic neurone blockade and is dependent on uptake into and concentration in peripheral adrenergic neurones. This mechanism, Uptake ${ }_{1}$, is blocked by the tricyclic compounds (Iversen, 1971).

Conolly et al. (1969) reported that the hypotensive action of clonidine in one patient appeared to be impaired by the introduction of imipramine $75 \mathrm{mg} /$ day. Recently we (Briant and Reid, 1972) showed that the hypotensive action of clonidine in rabbits is reduced about twentyfold by pretreatment with another tricyclic antidepressant, desipramine.

The present study was carried out to determine whether this interaction occurs in man.

\section{Materials and Methods}

Five hypertensive patients on long-term medication with clonidine and a diuretic were asked to join the study. After the

\footnotetext{
M.R.C. Clinical Pharmacology Research Group, Royal Postgraduate Medical School, London W12 0HS

ROBIN H. BRIANT, M.B., M.R.A.C.P., Wellcome Research Fellow in Clinical Pharmacology

COLIN T. DOLLERY, M.B., F.R.C.P., Professor of Clinical Pharmacology

Department of Medicine, Hammersmith Hospital, London W12 0HS JOHN L. REID, B.M., M.R.C.P., Senior Registrar
}

TABLE I-Details of the Patients Studied

\begin{tabular}{|c|c|c|c|c|c|}
\hline $\begin{array}{l}\text { Case } \\
\text { No. }\end{array}$ & Sex & Age & $\underset{(\mu \mathrm{g} / \mathrm{Day})}{\text { Clonidine Dose }}$ & Diuretic & $\begin{array}{l}\text { Duration of } \\
\text { Therapy (Years) }\end{array}$ \\
\hline 1 & F. & 47 & 600 & $\begin{array}{l}\text { Chlorthalidone } \\
100 \mathrm{mg} \text { alternate days }\end{array}$ & 3 \\
\hline 2 & M. & 43 & 3,200 & Hydrochlorothiazide & 2 \\
\hline 3 & M. & 41 & 1,050 & $\begin{array}{c}\text { Hydrochlorothiazide } \\
50 \mathrm{mg} \text { daily }\end{array}$ & 3 \\
\hline 4 & M. & 63 & 1,500 & $\begin{array}{l}\text { Hydrochlorothiazide } \\
50 \mathrm{mg} \text { daily }\end{array}$ & 3 \\
\hline 5 & M. & 45 & 1,800 & $\begin{array}{l}\text { Chlorthalidone } \\
100 \mathrm{mg} \text { alternate days }\end{array}$ & 3 \\
\hline
\end{tabular}

investigation had been explained to them all freely consented. Details of the patients are given in table I.

In each patient the same daily dose of clonidine and diuretic was maintained throughout the study, which was divided into three parts. The first was a period of baseline observation to ensure that control was adequate and consistent. The blood pressure, lying and standing, was measured with a sphygmomanometer on at least three occasions over at least three weeks. Several recordings were made at each visit, and the visits were kept as nearly as possible to the same time, most being made at the patient's home after work. Periods 2 and 3 each comprised two weeks during which the patient took either desipramine $75 \mathrm{mg} /$ day or the same number of matched placebo tablets. The patients were allocated at random to start with either placebo or desipramine and the study was carried out under double-blind conditions. During periods 2 and 3 the patients were seen at least twice a week.

Only one patient (case 3) did not keep to the agreed protocol. His blood pressure rose considerably 24 hours after beginning with the active drug. This was associated with headache and profuse sweating. A reduction in the desipramine dose resulted in a lessening of symptoms, but the blood pressure remained high so the study was terminated.

Average blood pressure for each patient was calculated from the whole run-in period and from the second week of each treatment period except in case 3 , where the comparative periods were week 1 of each treatment. Within-patient observations were compared by the unpaired Student's $t$ test, and group observations by the paired $t$ test.

\section{Results}

Four of the five patients showed a significant $(P<0.01)$ rise in blood pressure in at least one position on desipramine, while 